\title{
Obywatel dwóch narodowych kultur
}

\author{
Viskanju zgodbe Poljaka v izgnanstvu: Emil Korytko \\ (1813-1839) v Ljubljani / W poszukiwaniu losu Polaka \\ na wygnaniu: Emil Korytko (1813-1839) w Lublanie, \\ uredili Bogumila Plachtej Pavlin in Mateja Faletič, \\ Zbornik referatov in razprav št. 2/2019, Ljubljana: \\ Državni svet Republike Slovenije, 2019, 134 s.
}

\begin{abstract}
Darasz Zdzisław, Obywatel dwóch narodowych kultur (A Citizen of Two National Cultures). "Poznańskie Studia Slawistyczne" 19. Poznań 2020. Publishing House of the Poznań Society for the Advancement of the Arts and Sciences, Adam Mickiewicz University, pp. 405-419. ISSN 2084-3011.

Emil Korytko, a Polish student in Lwów (Galicia, Austrian partition), was arrested on accusations of activity in a Polish independence movement organisation. After over two years long investigation and imprisonment, he was exiled to Ljubljana (Laibach), the capital of Carniola. While living in exile, he collected and studied Slovene folk poetry and the customs of Carniola, thus becoming a pioneer of Slovenian ethnology and at the same time one of the most influential activists of Slovenian national awakening. In Slovenia he is known better than in his native country. In November 2013, the University in Ljubljana (Faculty of Philosophy) organized, in cooperation with the Embassy of Poland in Slovenia, a symposium dedicated to the celebration of the $200^{\text {th }}$ anniversary of his birth, including an exhibition about his life and career, held in the National and the University Library of Slovenia. In June 2019 this exhibition, supplemented by several documents, was held in the Slovenian Parliament as a celebration of the $180^{\text {th }}$ anniversary of Korytko's death. The bilingual book presented here reflects these cultural celebrations and the current state of knowledge about Polish-Slovenian ethnographer, philologist, poet, and translator.
\end{abstract}

KeYwords: Emil Korytko; Slovene folk poetry; Slovene national movement; Illyrian movement; Polish-Slovenian cultural relations; memory politics

Przed z górą stuleciem ukraiński pisarz, slawista i społecznik Iwan Franko opublikował we Lwowie, w organie Towarzystwa Naukowego 
im. Tarasa Szewczenki, obszerne studium biograficzne o Emilu Korytce, „zapomnianym słowiańskim etnografie”. Stwierdzenie, od którego rozpoczął opowieść o losie i dokonaniach swojego zmarłego przed prawie siedmioma dekadami lwowskiego krajana, w odniesieniu do podmiotów kultury polskiej do dziś nie straciło na aktualności: „Імя Еміля Коритка мало кому відоме, особливо серед його найблизших земляків Поляків" (Франко, 1908, 82). Dlatego każdemu polskiemu autorowi, czy to uczonemu, czy publicyście podejmującemu temat związany z osobą Emila Korytki, galicyjskiego politycznego zesłańca w Krainie, animatora słoweńskiej folklorystyki, towarzyszy przekonanie o potrzebie spłacenia mu długu pamięci, tak jak towarzyszyło znanemu dziennikarzowi Grzegorzowi Smólskiemu, korespondentowi m.in. petersburskiego „Kraju”, gdy już w roku 1882 pisał do swoich czytelników z Lublany: „Rodak nasz, o którym do dziś dnia z czcią i wdzięcznością słoweńcy wspominają, może też i wcale polskiej publiczności znanym nie jest" (Smólski, 1882, 7) ${ }^{1}$.

W ciągu ponad stulecia, jakie minęło od publikacji Iwana Franki, jednej z pionierskich dla tematu polsko-słoweńskiego ludoznawcy, stan wiedzy o nim wzbogacały z pokolenia na pokolenie prace przedstawicieli różnych dyscyplin humanistycznych: etnologii, nauki o literaturze, historii ruchów społecznych i narodowych, międzysłowiańskich związków kulturalnych. Nawet jeśli się pojawiały z rzadka, miały dość czasu na zestawienie całkiem sporej bibliografii przedmiotowej, która jednak odsłania wielką asymetrię informacji, jakie do niej wnieśli badacze polscy i słoweńscy, jednoznacznie rozstrzygając o prymarnie słoweńskiej afiliacji kulturowej młodego Polaka. Tak było i tak pozostanie, jest bowiem Korytko bez porównania intensywniej obecny w narodowej pamięci i świadomości Słoweńców niż swoich etnicznych współplemieńców.

Dla pozyskania podstawowej wiedzy o ludziach zaistniałych w naszej historiografii, kulturze i nauce zwykliśmy sięgać najpierw po encyklopedie, leksykony, słowniki biograficzne. Poszukującym informacji o Emilu Korytce oczywiście nie sprawia zawodu nieoceniony Polski stownik biograficzny, zawierający (w tomie XIV, 1968-1969) jego biogram autorstwa Juliana Maślanki, cenionego znawcy romantycznej folklorystyki, głównie

${ }^{1} \mathrm{~W}$ cytatach pisownia oryginalna. 
dorobku Zoriana Dołęgi Chodakowskiego. Ten sam badacz przedstawił Korytkę w krótkim haśle osobowym w Literaturze polskiej. Przewodniku encyklopedycznym (1986, wyd. 2) 2. Ale już w trzydziestojednotomowej Wielkiej encyklopedii PWN (2001-2005) miejsca dla lwowsko-lublańskiego etnografa zabrakło.

Nie jest sprawą przypadku, że najbardziej zasłużony - w międzynarodowej, słowiańskiej skali - strażnik pamięci o Emilu Korytce objawił się w jego rodzinnym Lwowie ${ }^{3}$, dokąd naturalną koleją rzeczy trafiła znaczna część rękopiśmiennego spadku po nim, w tym korespondencji. Papiery te zawdzięczają ocalenie przede wszystkim Sewerynowi, młodszemu bratu Emila, który je z pietyzmem przechowywał, zanim się znalazły w jednym z antykwariatów (Leeming, 1982, 431). Tam nabył je doktor Franko, posłużył się nimi do napisania pracy zacytowanej na początku niniejszego omówienia, po czym odstąpił je zainteresowanym Słoweńcom, co poskutkowało m.in. wieloodcinkowym artykułem France Kidriča Paberki o Korytku in dobi njegovega delovanja v Ljublja$n i$, drukowanym w siedmiu numerach miesięcznika „Ljubljanski Zvon” w roku 1910. W pokoleniu Kidriča historia słoweńskiej literatury, z czasem zyskująca mocne instytucjonalne oparcie w ustanowionym $\mathrm{w}$ roku 1919 Uniwersytecie w Lublanie i w Słoweńskiej Akademii Nauk i Sztuk (1938), miała znakomite przedstawicielstwo także w osobach Ivana Prijatelja i Ivana Grafenauera; wszyscy trzej uczeni - badacze i dydaktycy

${ }^{2}$ Hasło zawiera błąd pozornie literowy, a faktycznie fałszujący informację o miejscu urodzenia Korytki „w Rzeszowie pod Zaleszczykami” (s.v.). Lapsus jest raczej rysą na wizerunku Państwowego Wydawnictwa Naukowego niż zaniedbaniem autora hasła, który w odnośnym biogramie w Polskim słowniku biograficznym zapisuje nazwę rodzinnej wsi Korytki w zasadzie poprawnie, tylko bez diakrytu: „Ur. 7 IX [1813] w Rzezawie niedaleko Zaleszczyk”. Miejscowość ta, nosząca dziś miano Zełenyj Haj, do roku 1946 nazywała się Żeżawa (ukr. Жежава), która to nazwa ma w Słowniku geograficznym Królestwa Polskiego i innych krajów słowiańskich także wariantywny zapis Rzeżawa. Chwiejna ortografia toponimu przyczyniała się, jak w przytoczonych przykładach, do jego zniekształceń skutkujących dezinformacją.

${ }^{3}$ Siła związków Emila Korytki ze Lwowem, miastem jego edukacji i wcześniejszej społecznej aktywności, tłumaczy, dlaczego niektóre źródła podają za miejsce jego urodzenia galicyjską metropolię. Taka zresztą informacja widnieje w epitafium na jego nagrobku pod arkadami lublańskiego parku pamięci Navje: „Emilowi Korytko / najlepszemu Synowi / Rodzice / ur. w Lwowie 1813 r. zm. w Lubianie 1839”. Niezgodność informacji z biograficzną faktografią nie podważa powszechnego wśród badaczy życia i dzieła Korytki przekonania o jego lwowskiej identyfikacji środowiskowo-kulturalnej. 
ojczystego języka i literatury w słoweńskim szkolnictwie, walnie się przyczynili do ugruntowania i poszerzenia wiedzy o Korytce w slawistyce rodzimej i międzynarodowej.

Studium Iwana Franki inspirująco oddziałało również na krakowskie środowisko slawistyczne, skupione wokół miesięcznika „Świat Słowiański" (1905-1914) redagowanego przez historyka i historiozofa Feliksa Konecznego. W 7. roczniku tego organu „Klubu Słowiańskiego” Jan Magiera ogłosił artykuł Pamięci Emila Korytki, w którym z bardzo dobrym wyczuciem proporcji i równowagi między komponentami biograficznej opowieści, kreślonej z myślą o rodakach bohatera prezentacji, przedstawił jego dokonania i zasługi dla narodowego upodmiotowienia Słoweńców i kulturalnego zbliżenia słoweńsko-polskiego. Naturalnie Korytko nie przybył do Lublany jako emisariusz wolności, wprost przeciwnie: razem ze swoim towarzyszem zesłania Bogusławem Horodyńskim, ziemianinem ze Zbydniowa nad Sanem, listopadowym powstańcem, trafił tam z wyroku austriackiego sądu, przed którym stanął pod zarzutem działalności spiskowej (Horodyński był ponadto oskarżony o przerzut oddziałów powstańczych z Galicji za kordon - do Królestwa Polskiego). Z braku mocnych dowodów zostali po długim śledztwie i uwięzieniu uwolnieni od najcięższego zarzutu zdrady stanu, Korytce udowodniono tylko organizowanie druku (w Zakładzie Ossolińskich) i kolportażu Mickiewicza Ksiag narodu polskiego i pielgrzymstwa polskiego, jednakże jako bardzo podejrzani polscy patrioci, a zwłaszcza sympatycy i przyjaciele „listopadowych rozbitków”, musieli opuścić Lwów i pod policyjnym nadzorem udać się na internowanie do Lublany.

W kilkunastotysięcznym stołecznym mieście Krainy polscy zesłańcy szybko nawiązali w kręgu kulturalnych elit stosunki towarzyskie, których atrakcyjność łagodziła im - na ile to było możliwe w warunkach drastycznego ograniczenia swobód osobistych i obywatelskich - traumę przymusowej rozłąki z bliskimi ludźmi i sprawami. Cokolwiek czynili, musieli być politycznie czujni i ostrożni, aby nie przekreślić swoich szans na ułaskawienie, o co obydwaj zabiegali. Korytko wnet znalazł sposób na przekucie klęski w sukces - na takie zorganizowanie sobie życia i ukierunkowanie swoich zainteresowań, ażeby działając w granicach realiów czasu i miejsca, móc się spełniać w służbie romantycznym ideałom wolności i braterstwa ludów. Ze szczerym entuzjazmem oddał się zbieraniu słoweńskiego 
poetyckiego folkloru i artefaktów kultury ludowej, uczył się języków południowych Słowian, kreślił śmiałe projekty translatorskie, uwzględniając w nich nawet Osmana Ivana Gundulicia. Dla swoich akcji pozyskał na ziemiach słoweńskich licznych sympatyków i nawet współpracowników, którzy mu dostarczali interesujących go materiałów, prowadził ożywioną korespondencję z przedstawicielami środowisk naukowo-kulturalnych w Galicji i w Czechach. W odniesieniu do pracy zbieracza tekstów folkloru żywił przekonanie, wówczas jeszcze nie całkiem powszechne, iż „pieśni ludowe zapisywać należy tylko tak, jak je śpiewak śpiewa, nigdy inaczej”, bowiem „ludowe pieśni poprawiać, znaczy tyle, co je psuć”; ponadto „należy zapisywać także waryanty, gdzie myśl lub uczucie zmienione" (cyt. za: Magiera, 1911, 199). Dynamika realizacji najważniejszego z projektów, jakie sobie nakreślił, była zdumiewająca: niespełna dwa lata musiały mu wystarczyć na zgromadzenie i wstępne przygotowanie do druku w zakładzie lublańskiego typografa Jožefa Blaznika utworów poezji ludowej, które w rezultacie dały zbiór Şlovénşke péşmi, krajnfkiga naróda opublikowany w pięciu tomach formatu ósemki małej w latach 1839-1844. A przecież to emblematyczne dzieło słoweńskiej kultury powstawało w okolicznościach utrudniających systematyczny, racjonalnie rozplanowany proces twórczy ${ }^{4}$. Wiele czasu musiał młody badacz marnować na sporządzanie odpisów zebranych materiałów dla wiedeńskiego urzędu cenzury, na ubieganie się o prawo do podróżowania po Krainie, także na przezwyciężanie problemów finansowych, trzeba bowiem pamiętać, że zesłańcy żyli w Lublanie na własny koszt. Dlatego w korespondencji Emila z rodziną pojawiały się prośby o materialne wsparcie jego zamiarów, dla którego to wsparcia syn, brat i szwagier był zdecydowany nawet zrezygnować z należnej mu części przyszłego spadku. W tej sytuacji tym bardziej zasługuje na szacunek i podziw siła charakteru i prawość młodzieńca, który okazał się nieprzekupny wobec lublańskiego gubernatora Josepha Schmidburga. Otóż wysoki urzędnik c.k. administracji przymówił się Korytce o dedykowanie mu

${ }^{4} \mathrm{O}$ warunkach życia internowanych czytamy: „Policya otrzymała ścisłe i surowe przepisy nadzoru nad nimi. Dwakroć na dobę odwiedzać miano ich mieszkania, każdy list do nich adresowany miał być odpisany, skąd i kiedy przysłany, a odpisy natychmiast wysyłane do Wiednia. Podobne polecenie otrzymał urząd pocztowy, aby donosił, kiedy i jaki list i do kogo wysyłać będzie który z internowanych. Nie mniejszą czujność rozpostarto nad ich życiem i znajomościami” (Magiera, 1911, 197). 
zbioru słoweńskich pieśni ludowych, którego edycję gotów był w zamian sfinansować. Propozycja miała za sobą sankcję zwyczaju, który jednak uczonemu idealiście wydał się praktyką upokarzającą, niegodną człowieka honoru. Dzieła swojego życia znakomicie się zapowiadający slawista ludoznawca nie zdążył zobaczyć - zmarł 31 stycznia 1839 roku na chorobę rozpoznaną i wpisaną do policyjnego protokołu jako „kataralna gorączka reumatyczna", a diagnozowaną również jako tyfus. Jego pogrzeb przemienił się w wielką patriotyczną manifestację mieszkańców Lublany.

Artykuł Jana Magiery, mający za bibliograficzną bazę głównie prace Ivana Prijatelja, Iwana Franki i France Koblara, sam stał się z kolei oparciem dla polskich autorów, którzy na obszarach swoich dociekań napotykali - idąc mu świadomie naprzeciw albo nie mogąc go ominąć lublańskiego lwowianina. Kilka akapitów poświęcił mu Feliks Koneczny w przeglądzie Wplywy polskie w zachodniej Słowiańszczyźnie (prócz literackich), którym dopełnił dwutomowy zbiór Polska w kulturze powszechnej (1918) pod własną redakcją. Parę lat później tenże autor przywołał go w swojej historiozoficznej rozprawie Polskie Logos a Ethos. Roztrzasanie o znaczeniu i celu Polski (1921).

Współcześnie wzmiankują Korytkę, a niekiedy czynią go pierwszoplanową postacią swoich studiów, eksploratorzy słabiej rozpoznanych albo zaniedbanych sektorów polskiej slawistyki: językoznawczej (Bożena Ostromęcka-Frączak, Władysław Kupiszewski, Władysław Kryzia), literaturoznawczej (Joanna Wiśniewska-Krupa), historycznej (Antoni Cetnarowicz). Ich pisma łagodzą kategoryczność sądu o zupełnej nieznajomości Korytki w Polsce, ale z drugiej strony przekonują, jak słaba jest transmisja treści publikacji wąskospecjalistycznych do wiedzy ogółu społeczeństwa. Wspólnotowa (tożsamościowa) świadomość „ogółu” krystalizuje się bowiem w toku edukacji powszechnej, która większości obywateli daje kulturalną wyprawkę na całe życie. Skoro więc zasadnie twierdzimy, że in gremio jest Korytko znany w Słowenii, ale nie w Polsce, to dlatego, że od dawna ma otwarty dostęp do szkoły słoweńskiej, ale nie polskiej. Najmocniejszym zaś jego promotorem w słoweńskiej oświacie był France Prešeren - poetycki geniusz, o którym każdy Słoweniec wyniósł ze szkoły elementarny zasób wiedzy, nawet jeśli zakończył edukację na stopniu podstawowym. Ucząc się zaś o Prešernie, najprawdopodobniej przyswajał sobie - choćby niechcący - wiele informacji o ludziach, pośród których 
narodowy wieszcz żył i tworzył: o mecenasie Crobacie i jego rodzinie (żona prawnika była Polką), o Matii Čopie, Andreju Smolem, Emilu Korytce. Stąd, czyli ze szkoły, blisko już było do publicznej przestrzeni symbolicznej: Korytkę upamiętniła Lublana w swojej urbanonimii, nadając jego imię jednej z ulic na Vodmacie, i to nie „pierwszej lepszej”, ale ulicy, przy której się dzisiaj znajduje Wydział Medyczny Uniwersytetu w Lublanie i jego organizacyjne jednostki - instytuty, katedry, kliniki, dzięki czemu nazwa ulicy ma w słoweńskiej przestrzeni komunikacyjnej obieg bardzo intensywny. Warto dodać, że ta inicjatywa nazewnicza jest zasługą legendarnego burmistrza Lublany Ivana Hribara (1851-1941).

W 2019 roku pojawiła się w Słowenii publikacja o Korytce, zaskakująca zarówno swoim charakterem, jak i adresem edytorskim, ponieważ wydała ją Rada Państwa (Državni svet), izba wyższa dwuizbowego parlamentu Republiki Słowenii. Izba ta ma status przedstawicielstwa interesów socjalnych, gospodarczych, zawodowych i lokalnych (terytorialnych). Odpowiednio do swoich kompetencji organizuje konferencje i narady przedmiotowych specjalistów, dokumentowane publikacjami składającymi się na serię „Zborniki referatov in razprav”. I oto pośród dziesiątków profesjonalnie wyprofilowanych wydawnictw, służących optymalizacji metod rozwiązywania praktycznych problemów słoweńskiego społeczeństwa: politycznych, ekologicznych, zdrowotnych, kulturalnych, oświatowych, energetycznych, komunikacyjnych etc., napotykamy dwujęzyczny, słoweńsko-polski tom poświęcony historycznej postaci sprzed dwóch stuleci. Pierwsze odczucie zaskoczenia słabnie jednak pod wpływem refleksji, że rzecz dotyczy przecież społeczeństwa, które między swoje święta państwowe (dni wolne od pracy) policzyło Święto Słoweńskiej Kultury, zwane też Dniem Prešerna, a przypadające na dzień 8 lutego - rocznicę śmierci poety. W projekt aktualnej syntezy wiedzy o Polaku aktywnym w procesie słoweńskiego odrodzenia narodowego zaangażowały się państwowe instytucje obydwu jego duchowych ojczyzn: tej, która w geopolitycznym kształcie zniknęła z mapy Europy niespełna dwie dekady przed jego narodzinami, i tej, która w takim kształcie miała się na niej pojawić dopiero po upływie półtora wieku. Inicjatywę wydania publikacji poświęconej Emilowi Korytce, podjętą przez przedstawicielski organ władzy Republiki Słowenii, wsparła Ambasada Rzeczypospolitej Polskiej w Lublanie. 
Edycję poprzedziły i przygotowały dwa jubileusze obchodzone w Słowenii w poprzedniej dekadzie. W roku 2013 było to dwustulecie urodzin Korytki, upamiętnione naukowym sympozjum „Emil Korytko (1813-1839) v izgnanstvu v Ljubljani - Vloga poljskega emigranta, humanista in etnografa v narodnem prerodu". Zorganizowane przez Katedrę Polonistyki Wydziału Filozoficznego Uniwersytetu w Lublanie odbyło się w uniwersyteckiej auli 7 listopada, a towarzyszącą mu imprezą była ekspozycja świadectw i dokumentów działalności bohatera jubileuszu urządzona w Bibliotece Narodowej i Uniwersyteckiej. W roku 2019, w którym upłynęło 180 lat od śmierci Korytki, wystawę tę, powiększoną o nowe eksponaty, zainstalowano w prestiżowej przestrzeni parlamentu, nadając jej status wydarzenia o randze państwowej, a z uwagi na zaangażowanie strony polskiej w obchody rocznicy - także międzynarodowej. Teksty posympozjalne i materiały ikonograficzne, po części wykorzystane na wystawach, złożyły się na wieloautorską monografię o Korytce, jakiej dotąd nie było ani u Słoweńców, ani tym bardziej u Polaków. Ze względu na jubileuszowo-komemoratywne i środowiskowe okoliczności powołujące ją do istnienia można się w niej dopatrzyć cech sugerujących jej afiliację raczej polityczną (w rozumieniu polityki pamięci) niż „bezinteresownie” naukowo-badawczą, trzeba jednak stanowczo stwierdzić, że okazjonalny, popularyzatorski charakter wydawnictwa nie szkodzi jego akademickiemu merytorycznemu standardowi, jaki mu gwarantują autorzy - profesorowie lublańskiego uniwersytetu i akademii nauk, najlepsi znawcy tematu. Polskojęzyczne wersje ich prac podały do druku tłumaczki: Marzena Ewa Krajewska, Bogumila Plachtej Pavlin, Aleksandra Pintarič Kaczyńska i Joanna Sławińska. Oryginał nakreślonego przez Marzenę Ewę Krajewską, I radcę ambasady Rzeczypospolitej Polskiej w Lublanie, obrazu polsko-słoweńskich więzi kulturalnych, widzianego przez pryzmat zsyłkowej opresji Korytki, przełożyła na słoweński Lidija Rezoničnik.

Zanim przemówią ludzie nauki, głos zabierają ludzie polityki i dyplomacji: przewodniczący Rady Państwa Republiki Słowenii Alojz Kovšca i ambasador Rzeczypospolitej Polskiej w Lublanie Paweł Czerwiński. Ich wypowiedzi otwierające tom referatów, skomponowane w rejestrach stylu podniosłego dla potrzeb wydarzenia sławiącego znamienitą postać historii kultury, są - rzec by można - retorycznymi wariacjami na poetycki temat wielkości i trwałości ludzkiego dzieła, najlapidarniej ujęty 
w czterowierszu, jaki France Prešeren położył na przedwczesnym grobie przyjaciela i nauczyciela: „Der Menßch mußs untergehen / Die Menßchheit bleibt fortan / Wird mit ihr das beftehen / Was er für sie gethan".

W naukową debatę nad udziałem i znaczeniem ,polskiego emigranta, humanisty i etnografa" w narodowym odrodzeniu słoweńskim wprowadza referat historyka Igora Grdiny Korytkova doba in podoba. Historyczny czas młodego Polaka internowanego w Ilirii to epoka ministra cesarskiego dworu i ministra spraw zagranicznych Klemensa von Metternicha, polityka skrajnie konserwatywnego, zaciekłego przeciwnika ruchów rewolucyjnych i niepodległościowych, architekta państwa policyjnego, w którym inwigilacja i cenzura bardzo zyskały na znaczeniu jako narzędzia sprawowania władzy. Kto inny, jeśli nie obydwaj Galicjanie zesłani między Słoweńców, mógłby tę charakterystykę austriackiego męża stanu lepiej uwierzytelnić. Ale też i dociekliwy czytelnik musi w tym miejscu postawić pytanie, jak w monarchii habsburskiej, i to właśnie w epoce kanclerza Metternicha, było możliwe godzenie rządów autorytarnych z nasilonym procesem transformacji ludów w narody. Pierwsza odpowiedź na to pytanie streszcza się najtrafniej w dewizie Divide et impera - fundamentalnej zasadzie władzy sprawowanej w polu napięć między wieloma skonfliktowanymi interesami różnych wspólnot, także narodowych, zasadzie najskuteczniej zabezpieczającej interesy własne tych, co władzę sprawują. W przyzwoleniu na działania podejmowane przez elity mniejszościowych społeczności etnojęzykowych dla dobra ich kulturalnego awansu widział Metternich antidotum na polityczny nacjonalizm węgierski, którego imperialne aspiracje były niebezpieczne tyleż dla monarchii, co i dla niemadziarskich narodów Królestwa Węgier: Chorwatów, Serbów, Rumunów, Słowaków, Rusinów. Z tej przyczyny nie przeciwdziałał iliryzmowi Ljudevita Gaja, pozostającego w konflikcie politycznych interesów z Węgrami, ale nieprzerwanie sprawował kontrolę nad ruchem, który w latach 40. XIX wieku z jego nakazu zmienił imię z iliryjskiego na chorwackie, zmieniając tym samym - niejako pod politycznym przymusem - swoje priorytety z południowosłowiańskich na kroatocentryczne. Za osobliwy patronat kanclerza odpłacał Gaj deklaracjami lojalizmu wobec władzy, co potwierdza jeden z jego listów do Emila Korytki, datowany 4 grudnia 1838 roku. Korespondencja dotyczy druku Slovenskih pesmi krajnskiga naroda, którego Gaj miał się podjąć w Zagrzebiu zgodnie ze wstępnymi 
ustaleniami autora i wydawcy. Lider iliryzmu w obawie przed podejrzeniem o nielojalność, jakie mogłyby na niego ściągnąć kontakty z polskim politycznym zesłańcem, wycofał się z podjętego zobowiązania (Bleiweis, $1875,172-173)$.

Drugie wythumaczenie tolerancyjnego stosunku Metternicha do ruchów kulturalnej emancypacji „niepaństwowych” narodów cesarstwa Habsburgów podsuwa passus o pozytywnej korelacji pomiędzy skutkami terezjańskiej reformy szkolnictwa a nasileniem dynamiki rozwoju gospodarki rolnej i przemysłu, co owocowało wzrostem poziomu życia społeczeństwa i siły fiskusa. Umiejętność pisania i czytania w znanym użytkownikowi języku otwierała mu dostęp do czasopism szerzących wiedzę praktyczną z dziedziny rolnictwa i rzemiosła, a nawyk systematycznej lektury dobroczynnie wpływał na jego umysłową kulturę. Wydaje się, że pierwszy inżynier mentalnej przestrzeni naddunajskiego imperium nie oszacował należycie wartości tego najbardziej osobistego, intymnego dobra, jakie obywatel mógł zyskać, jeśli chciał, z udziału w programie powszechnego oświecenia, czyli wartości samorealizacji; przyuczony do podnoszenia jakości uprawy swoich rolnych kultur, mógł optymalizować również uprawę własnej kultury intelektualnej.

Trzeciej odpowiedzi na rozpatrywaną tu kwestię w krótkim referacie Igora Grdiny już nie ma, ale można po nią sięgnąć do innego źródła. Jak pisze Henryk Wereszycki, największego zagrożenia dla porządku prawnego w państwie, dla stabilności i trwałości jego instytucji upatrywał Metternich nie w dążeniach inteligencji ,niehistorycznych” ludów do ich przemiany w narody, lecz w szerzącej się ideologii niemieckiego liberalizmu, którego pociągającą dla wielu obywateli społeczną siłę próbował neutralizować energią narodotwórczych procesów w monarchii (Wereszycki, 1986, 176-181).

Nakreślona przez Nikolaja Ježa Podoba Emila Korytka v slovenski kulturni zgodovini to modelowo syntetyczne, a tym samym bardzo użyteczne edukacyjnie ujęcie tytułowego zagadnienia. Mocno zżyty ze swoim literackim bohaterem jako tłumacz jego korespondencji na język słoweński jest profesor Jež, najbardziej dziś czynny i zasłużony polonista w Słowenii, wybitnym znawcą macierzystego dla Korytki, czyli lwowskiego środowiska kulturalnego, w którym w latach 1822-1827 przebywał i pracował w gimnazjum i na uniwersytecie Matija Čop, niepospolitej miary młody 
uczony z najbliższego otoczenia France Prešerna, filolog klasyczny. Po jego tragicznej śmierci w roku 1835 opuszczone przezeń miejsce w kręgu słoweńskiego narodowego wieszcza zdumiewający zbieg zdarzeń oddał do zagospodarowania - nie na długo, bo tylko na dwa lata - przybyszowi z miasta, które w biografii Čopa odegrało rolę nadzwyczaj ważną, porównywalną z rolą Lublany w życiu Korytki. W świadomości słowenistów i polonistów prace Nikolaja Ježa, tłumacza i współwydawcy korespondencji obydwu słowiańskich budzicieli związanych ze Lwowem i z Lublaną, ustanawiają między nimi więzi, które w świecie realnym zaistnieć nie mogły (za lwowskich lat Čopa Korytko był jeszcze dzieckiem).

Miarą znaczenia historycznych postaci dla potomnych jest nie tylko ich obecność w aktualnych kanonach edukacyjnych, ale też siła atrakcyjna, z jaką mogą jeszcze oddziaływać na wyobraźnię i wrażliwość współczesnych twórców kultury. W odróżnieniu od Polaka Słoweniec może napotkać Korytkę zarówno w polu humanistycznych nauk, jak i w sztuce. Autorzy biograficznych powieści o Prešernie: Ilka Vašte (Roman o Prešer$n u, 1937)$ i Anton Slodnjak (Neiztrohnjeno srce, 1938), wprowadzili go do swoich światów przedstawionych w roli osoby z wąskiego towarzyskiego kręgu poety; również twórcy pięcioodcinkowego filmu telewizyjnego Prešeren (1999-2000) i jego kinowej wersji Pesnikov portret z dvojnikom (2002): scenarzyści Matjaž Kmecl i Branko Šömen oraz reżyser Franci Slak, nie mogli go wyłączyć z gromadki ludzi Prešernowi najbliższych. Filmowego wizerunku użyczył mu znany aktor Primož Ekart. Już bez „protekcji” pierwszego pośród słoweńskich poetów zaistniał Korytko na scenie w dramatycznej adaptacji jego korespondencji z rodziną (Korespondenca z družino), dokonanej przez Marka Slodnjaka (1946-1984) i wystawionej przez Jožego Babiča (1985). W tejże korespondencji, w liście do szwagra Korytki Józefa Jasińskiego, prozaik i dramaturg Drago Jančar natrafił na fragment o powstańcu Sewerynie Drohojowskim, którego tułaczy los przywiódł na chwilę do Lublany parę lat przed Korytką i którego przypadek zainspirował pisarza do napisania dramatu Veliki briljantni valček (1985) - niebywale pojemnej semantycznie i funkcjonalnej interpretacyjnie przenośni świata totalitarnej przemocy systemu nad jednostką.

Marija Stanonik cytatem w tytule referatu Emil Korytko (1813-1839) in ,njegov program [...] glede slovenske folkloristike” (I. Prijatelj) (Prijatelj, 1908, 611) przywołuje badacza, który z korespondencji prowadzonej 
przez ludoznawczego zapaleńca ze sprzymierzeńcami ruchu kulturalnego odrodzenia Słowian, w tym z redakcjami pism (lublańskiego „Illyrisches Blatt”, praskiego „Ost und West”) pierwszy wyczytał spójne założenia i postulaty odnośnie do działań na rzecz ocalenia dóbr kultury ludowej także Słoweńców, jeszcze nierozbudzonych romantyczną fascynacją folklorem. Swoich korespondentów prosił o informacje dotyczące zagadnień ujętych w kwestionariuszu, a związanych z takimi aspektami życia jak: obrzędy wesela, chrztu i pogrzebu; zwyczaje bożonarodzeniowe, równonocne i świętojańskie; muzyka i tańce; przesądy, wróżby i przepowiadanie pogody; demonologia, zamawiania i egzorcyzmy; czary i ich sprawczynie; medycyna ludowa; symbolika kultury ludowej, maksymy i przysłowia; pieśni świeckie zapisane od wykonawców; baśnie, bajki i opowiadania; stroje (tu pożądane ilustracje); życie domowe, rodzinne i społeczne - gościnność, pomoc wzajemna w sąsiedztwie, piętnowane występki i sławione cnoty, ich częstotliwość (Prijatelj, 1908, 606; Novak, 1972, 30-31).

Marija Klobčar, etnomuzykolożka ze Słoweńskiej Akademii Nauk i Sztuk, w prezentacji Emil Korytko in zbirka Slovenske pesmi krajnskiga naróda przybliża główne i w gruncie rzeczy jedyne zrealizowane, choć niezupełnie po myśli autora, dzieło pioniera słoweńskiej etnologii. Ukazane w kontekście jego śmiałych projektów, jawi się jednak nie tyle jako odniesiony, choćby pośmiertnie, znaczny sukces, ile jako ilustracja dramatu niespełnienia. Za swoje posłannictwo uznał bowiem Korytko, uskrzydlony porywającą a szczęśliwie bezczelną odwagą młodości, zabraniającą „kłaniać się okolicznościom", porównawcze ujęcie słowiańskich kultur w ogromnej monografii Słowiańszczyzna, ku której miała go doprowadzić praca rozpoczęta na kraińskiej niwie. Tymczasem trzeba było usuwać przeszkody (organizacyjne, techniczne) z drogi do celu najbliższego, czyli edycji zbioru Slovenske pesmi krajnskiga naróda w zmienionym zakładzie typograficznym - w Lublanie u Blaznika zamiast w Zagrzebiu u Gaja, jeszcze czcionkami tradycyjnej bohoričicy zamiast upowszechniającej się właśnie gajicy. Co najgorsze, pieśni zostały wydrukowane bez przygotowanych zapisów nutowych; nie wiadomo, kiedy i w jakich okolicznościach te muzyczne notacje przepadły, dotkliwie zubożając poznawczy zasób zbioru i przez to wyrządzając niepowetowaną szkodę słowiańskiej etnomuzykologii.

Na kanwie opracowanego przez Korytkę programu badań nad słoweńską kulturą ludową zasadza się również wystąpienie Terensko delo 
Emila Korytka na slovenskem ozemlju, będące streszczeniem pracy dyplomowej Teuty Imeri. Obecność tekstu młodej autorki w prezentowanej tu publikacji cieszy szczególnie jako potwierdzenie ciągłości zainteresowań okazywanych dokonaniom Korytki przez kolejnych słoweńskich budowniczych tradycji kultury macierzystej i powszechnej. Pożyteczny ten referat w znacznym stopniu pomniejsza deficyt naszej wiedzy o warunkach, w jakich przebiegały terenowe eksploracje kraińskiego folkloru, dokumentowane doraźnymi zapiskami sporządzanymi po polsku, bez dbałości o czytelność, bo przecież miały służyć za wsporniki pamięci samemu badaczowi, który ich raczej nie postrzegał w perspektywie długiego trwania. Tymczasem okazuje się, że jeśli ich papierowych nośników nie unicestwiły czynniki atmosferyczne albo gryzonie, to po kilkunastu dekadach doczekały się czasów cyfryzacji, która im dała drugie życie. Niejeden z takich ocalonych rękopisów Teuta Imeri przetranskrybowała, przetłumaczyła na słoweński i skomentowała, wykorzystując w tym celu przede wszystkim studyjny pobyt na Uniwersytecie Warszawskim (Plachtej Pavlin, Faletič, 2019, 31).

Marzena Ewa Krajewska, spiritus movens upamiętnienia Emila Korytki okolicznościową wystawą i publikacją, daje najbardziej sumaryczne i przeglądowe z zawartych w tomie ujęć i zbliżeń ,polskiego emigranta, humanisty i etnografa" w referacie Poljsko-slovenske kulturne vezi v luči izgnanstva Emila Korytka v Ljubljano. Jest oczywiste, że zawiera on treści czerpane z kanonu wiedzy o Korytce przez wszystkich portretujących tego wyróżniającego się polskiego aktora słoweńskiej sceny publicznej w epoce Metternicha, ale ponadto przypomina pracę polonisty językoznawcy Władysława Kupiszewskiego Język listów Emila Korytki, za co należy się autorce uznanie dla jej przedmiotowych kompetencji - tym bardziej, że w polskim artykule sprzed kilku lat, najściślej związanym problemowo z bogatą epistolografią Korytki, nie ma żadnego odniesienia do tego studium.

Zapewne niejednego spośród czytelników, którzy z potrzeby albo z ciekawości sięgną po recenzowaną książkę, zaskoczy odkrycie w Korytce, kulturoznawcy sensu largo, również praktykującego artysty słowa - poety biegłego w sztuce rymotwórczej. Redaktorki zbioru ilustrują jego literacki talent wierszami okolicznościowymi, ofiarowanymi rodzicom: matce Rudolfinie i ojcu Stanisławowi, oraz utworem pochwalnym adresowanym 
Do pięknych pań z Lublany. Sonet dla Mamy na imieniny i Drogiemu Ojcu na imieniny przełożył na słoweński Tone Pretnar, panegiryk dedykowany Lepim Ljubljančankam - Andrej Mrak.

Publikację zamykają informacje uzupełniające i komentarze do rocznicowych upamiętnień badacza kultury słoweńskiego ludu. O wystawie „Emil Korytko (1813-1839), poljski politični izgnanec, pesnik in etnograf. V iskanju zgodbe Poljaka v izgnanstvu" pisze jej autorka i koordynatorka Marzena Ewa Krajewska, Nikolaj Jež w przypomnieniu 180. rocznicy śmierci Korytki modeluje wizerunek tego wygnańca także poprzez odniesienia do utworów artystycznych, które zainspirował, na podobieństwo ,ikony romantycznego patriotyzmu”. Obydwoje autorzy korzystają z obfitego materiału ilustracyjnego, wydatnie podnoszącego poznawczy i estetyczny walor wydawnictwa.

Na wizerunkowy bilans księgi ujemnie natomiast wpływa niedopracowanie redakcyjne i podstandardowa - ze względu na formę - jakość tekstów przełożonych ze słoweńskiego na polski (ten drugi zarzut w najmniejszym stopniu, jeśli w ogóle, dotyczy tłumaczenia Joanny Sławińskiej). Trywialna czynność wykazywania uchybień składniowych, fleksyjnych, a nawet rzeczowych daleko by się jednak mijała z wysokim celem przyświecającym niniejszemu omówieniu słoweńskiej publikacji, która w polskim środowisku slawistycznym nie powinna pozostać bez odzewu, dlatego dobrze tu zrezygnować z erraty na rzecz uwydatnienia roli, jaką nasz rodak Emil Korytko odegrał w dziele kulturalnej, a tym samym narodowej emancypacji naszych słowiańskich pobratymców z pogranicza Śródziemnomorza, Europy Środkowej i Bałkanów.

\section{Literatura}

Bleiweis, J. (1875). Literarna zapuščina doktorja Franceta Prešerna. „Letopis Matice slovenske za leto 1875 ", s. 153-175.

Kidrič, F. (1910). Paberki o Korytku in dobi njegovega delovanja v Ljubljani. „Ljubljanski Zvon" 1. 30, s. 298-305, 364-368, 431-437, 490-497, 552-560, 682-688, $745-754$.

Leeming, H. (1982). Kontakty polsko-stoweńskie po r. 1830. Doświadczenia zesłańca. Przeł. S. Hołdys, M. Mróz. „Śląski Kwartalnik Historyczny Sobótka” R. 37, nr 3-4, s. 431-439. 
Magiera, J. (1911). Pamięci Emila Korytki. „Świat Słowiański” R. 7, t. 1, s. 192-207.

Novak, V. (1972). Emila Korytka nemški članki o slovenskem ljudskem izročilu. „Traditiones"1. 1, s. 27-52.

Plachtej Pavlin, B., Faletič, M. (ur.) (2019). V iskanju zgodbe Poljaka v izgnanstvu: Emil Korytko (1813-1839) v Ljubljani / W poszukiwaniu losu Polaka na wygnaniu: Emil Korytko (1813-1839) w Lublanie. Zbornik referatov in razprav, št. 2/2019. Ljubljana: Državni svet Republike Slovenije.

Prijatelj, I. (1908). Emil Korytko. In: Zbornik u slavu Vatroslava Jagića. Berlin: Weidmannsche Buchhandlung, s. 604-611.

Smólski, G. (1882). [Korespondencja z Lublany]. „Kraj” R. 1, nr 8, s. 7.

Wereszycki, H. (1986). Historia Austrii, wyd. 2. Wrocław: Ossolineum.

Франко, I. (1908). Еміль Коритко, забутий славянський етнограф. „Записки Наукового товариства імени Шевченка" т. 86, кн. 6, s. 82-122.

[Franko, I. (1908). Emil' Koritko, zabutij slavâns'kij etnograf, „Zapiski Naukovogo tovaristva ìmeni Ševčenka" t. 86, kn. 6, s. 82-122]. 